\title{
Pre-monsoon aerosol characteristics over the Indo-Gangetic Basin: implications to climatic impact
}

\author{
A. K. Srivastava ${ }^{1}$, S. Tiwari ${ }^{1}$, P. C. S. Devara ${ }^{2}$, D. S. Bisht ${ }^{1}$, Manoj K. Srivastava ${ }^{3}$, S. N. Tripathi ${ }^{4}$, P. Goloub ${ }^{5}$, and \\ B. N. Holben ${ }^{6}$ \\ ${ }^{1}$ Indian Institute of Tropical Meteorology (Branch), Prof Ramnath Vij Marg, New Delhi, India \\ ${ }^{2}$ Indian Institute of Tropical Meteorology, Dr Homi Bhabha Road, Pashan, Pune, India \\ ${ }^{3}$ Department of Geophysics, Banaras Hindu University, Varanasi, India \\ ${ }^{4}$ Department of Civil Engineering, Indian Institute of Technology Kanpur, Kanpur, India \\ ${ }^{5}$ Laboratoire d'Optique Atmosphérique, Lille University/CNRS, Villeneuve d'Ascq, France \\ ${ }^{6}$ NASA, Goddard Space Flight Center, Greenbelt, MD, USA
}

Received: 18 November 2010 - Revised: 28 April 2011 - Accepted: 5 May 2011 - Published: 11 May 2011

\begin{abstract}
Sun/sky radiometer observations over the IndoGangetic Basin (IGB) region during pre-monsoon (from April-June 2009) have been processed to analyze various aerosol characteristics in the central and eastern IGB region, represented by Kanpur and Gandhi College, respectively, and their impacts on climate in terms of radiative forcing. Monthly mean aerosol optical depth (AOD at $500 \mathrm{~nm}$ ) and corresponding Angstrom Exponent (AE at 440-870 nm, given within the brackets) was observed to be about 0.50 (0.49) and 0.51 (0.65) in April, 0.65 (0.74) and 0.67 (0.91) in May and $0.69(0.45)$ and 0.77 (0.71) in June at Kanpur and Gandhi College, respectively. Results show a positive gradient in AOD and AE from central to eastern IGB region with the advancement of the pre-monsoon, which may be caused due to diverse geographical location of the stations having different meteorological conditions and emission sources. Relatively lower SSA was observed at the eastern IGB (0.89) than the central IGB $(0.92)$ region during the period, which suggests relative dominance of absorbing aerosols at the eastern IGB as compared to central IGB region. The absorbing aerosol optical properties over the station suggest that the atmospheric absorption over central IGB region is mainly due to dominance of coarse-mode dust particles; however, absorption over eastern IGB region is mainly due to dominance of fine-particle pollution. The derived properties from sun/sky radiometer during pre-monsoon period are used in a radiative-transfer model to estimate aerosol radiative forcing at the top-of-the atmosphere (TOA) and at the surface over the IGB region. Relatively large TOA and surface cooling was observed at the eastern IGB as compared to the cen-
\end{abstract}

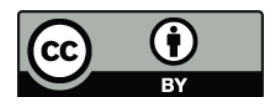

Correspondence to: A. K. Srivastava (atul@tropmet.res.in) tral IGB region. This translates into large heating of the atmosphere ranging from 0.45 to $0.55 \mathrm{~K} \mathrm{day}^{-1}$ at Kanpur and from 0.45 to $0.59 \mathrm{~K} \mathrm{day}^{-1}$ at Gandhi College.

Keywords. Atmospheric composition and structure (Aerosols and particles) - Meteorology and atmospheric dynamics (Radiative processes)

\section{Introduction}

Aerosols play crucial role in the climate of the Earthatmosphere system by means of their direct and indirect impact on climate (Schwartz et al., 1995). Nonetheless, there is a large uncertainty in the aerosol radiative forcing and hence in the assessment of global climate as well as climate change (IPCC, 2007). Though the level of scientific understanding of aerosols has been increased by incorporating in-situ measurements along with various satellite measurements, still it is far less than that of greenhouse gases (IPCC, 2007). Heterogeneity in aerosol optical and microphysical properties over a wide range of spatial and temporal scales could be one of the major causes of the difficulties in reducing the level of scientific understanding due to aerosols. Thus, it is important to improve aerosol characterization on regional basis with high spatial and temporal resolutions; particularly over the region, where high population is under the impact (Dey and Di Girolamo, 2010).

The Indian sub-continent is one of the highly populated regions in the world, where more than one billion people (about one-sixth of the world's population) live and, are exposed to enormous pollution produced by various natural and anthropogenic sources. The region strictly requires improvements in the characterization of aerosol properties, which

Published by Copernicus Publications on behalf of the European Geosciences Union. 
is basically due to the inadequate measurements of aerosol characteristics. Ever since the Indian Ocean Experiment (INDOEX) was conducted (Ramanathan et al., 2001; Moorthy et al., 2001), which has shown that enormous pollution transported from the Indian subcontinent to the adjacent oceanic regions affected the regional forcing significantly, the focus to characterize the aerosols over Indian landmass and adjacent oceans has intensified.

Further, over the northern part of India, information on aerosols is much limited, particularly, over the Indo-Gangetic Basin (IGB) region, which has been considered to be an important region of research interest due to its unique nature of topography and high population, as well as industrial density. Studies undertaken so-far, over IGB, indicate high emissions of various anthropogenic aerosols from different sources (Reddy and Venketaraman, 2002a, b; Di Girolamo et al., 2004; Ramanathan and Ramana, 2005; Tare et al., 2006; Tripathi et al., 2006; Rengarajan et al., 2007; Tiwari et al., 2010). Moreover, during pre-monsoon or summer seasons, IGB receives heavier loads of natural dust aerosols, transported from the neighboring Desert regions (Thar Desert) of western Rajasthan in India (Dey et al., 2004; Pandithurai et al., 2008; Gautam et al., 2009b; Srivastava et al., 2010b, c), which are the single largest contributor to the mineral dust aerosols over the northwest Indian regions (Todd et al., 2007). Desert-dusts are rarely found during March months, even April month found to have rare desert dust events (Srivastava et al., 2010b) and their frequency increases during the late pre-monsoon season, until the onset of monsoon. Higher frequencies of dust event occurrence have been found by Middleton (1986) in the western part as compared to the eastern part of the IGB, which is related to the increasing west to east pressure gradient caused by advancement of the summer season over IGB (Pandithurai et al., 2008). These dust particles are frequently lifted into the free troposphere and transported as elevated aerosol layers over long distances to impact in heating of the atmosphere and changing the radiation balance (Srivastava et al., 2010a, b). While transportation, dust mixes with various anthropogenic aerosols in the polluted environment (Singh et al., 2005; Dey et al., 2008), and the resulting optical properties and the associated radiative impacts becomes highly variable (Dey et al., 2008; Mishra et al., 2008).

Aerosols exhibit high spatio-temporal variability in terms of their abundance, optical and chemical properties. Although, satellites are the good tool to understand the broad spatio-temporal characteristics of aerosols over a wider region (Di Girolamo et al., 2004; Jethva et al., 2005; Prasad and Singh, 2007; Ramachandran and Cherian, 2008); they are unable to provide an in-depth view of aerosol properties on a local scale and pose higher uncertainties as compared to the ground-based instruments, particularly, during dust loading season (Tripathi et al., 2005; Prasad and Singh, 2007). NASA has setup ground-based aerosol monitoring network under the Aerosol Robotic Network (AERONET) program
(Holben et al., 1998), in which automatic sun/sky radiometers are deployed at various places around the world. As per India, particularly in the northern part, the routine measurements of aerosols under this network were started initially by the deployment of the automatic sun/sky radiometers at Kanpur over the IGB region in year 2001 (Singh et al., 2004). At a later stage, it was deployed at other places in the IGB, considering the region as crucial for aerosol measurements.

In view of the importance and sensitivity of aerosol properties over the IGB region, the present study has been carried out using ground-based automatic sun/sky radiometer data rather than the satellite-derived one. Sun/sky radiometer data were collected at two different stations located at Kanpur $\left(26.4^{\circ} \mathrm{N}, 80.4^{\circ} \mathrm{E}\right)$ and Gandhi College $\left(25.8^{\circ} \mathrm{N}, 84.2^{\circ} \mathrm{E}\right)$ during April to June 2009 to infer various aerosol properties and their impacts on radiative forcing with respect to the advancement of pre-monsoon months.

\section{Site description and experimental set-up}

The present study involves CIMEL sun/sky radiometer data measured at two different AERONET stations over the IGB region: (i) Kanpur $\left(26.4^{\circ} \mathrm{N}, 80.4^{\circ} \mathrm{E}\right)$, one of the highly polluted mega cities in Asia, situated in the central part of the IGB and (ii) Gandhi College (25.8 $\left.\mathrm{N}, 84.2^{\circ} \mathrm{E}\right)$, a sub-urban station, situated in the eastern part of the IGB. Both the sites are shown over the IGB region in Fig. 1a. For ready reference, the aerosol characteristics over the region have been plotted in Fig. 1a as mean aerosol optical depth (AOD) values from April to June 2009 at $550 \mathrm{~nm}$ in color code, obtained from Moderate Resolution Imaging Spectroradiometer (MODIS). Spatial gradient in AOD can readily be noticed from the Fig. 1a showing significant amount of aerosol particles (mostly dust aerosols during pre-monsoon) existing at the central IGB in comparison to the eastern part. Further, to understand the fine-mode AOD (aerodynamic radius $\leq 0.35 \mu \mathrm{m}$ ) distribution for the same period, data from Polarization and Anisotropy of Reflectances for Atmospheric Sciences coupled with Observations from a Lidar (PARA$\mathrm{SOL}$ ), is shown in Fig. $1 \mathrm{~b}$ in color code. Figure $1 \mathrm{~b}$ informs rather opposite feature of fine-mode AOD in comparison to the MODIS derived AODs over the region. Results obtained from the above observations, although, include the impact from prevailing meteorology, but encourages investigating further in the possible causes and impacts over radiationbudget as well as on weather and climate.

The CIMEL sun/sky radiometers deployed at the Indian Institute of Technology, Kanpur and Gandhi College, Ballia is part of AERONET/TIGERZ Program of NASA, USA. The instrument measures the direct Sun radiances at eight spectral channels $(340,380,440,500,670,870,940$ and $1020 \mathrm{~nm}$ ), where 940 and $1020 \mathrm{~nm}$ channels are used to estimate the columnar water vapor content, and remaining channels are used to retrieve spectral AODs. On the 
other hand, sky radiance measurements (in almucantar and principal plane) at four spectral channels $(440,670,870$, and $1020 \mathrm{~nm}$ ) are used to retrieve size distribution, single scattering albedo (SSA) and refractive indices of the aerosols (Holben et al., 1998). The processed aerosol related data are available on-line at the AERONET site (http: //aeronet.gsfc.nasa.gov/) in three categories: cloud contaminated (level 1.0), cloud screened (level 1.5) and quality assured (level 2.0) (Smirnov et al., 2000). Level 2.0 data is the final product of AERONET, which have been utilized for the present study for the period from April to June 2009. Out of total 3 months data, total 91 days data (30 days in April, 31 days in May and 30 days in June) were observed at Kanpur and 83 days data (28 days in April, 28 days in May and 27 days in June) at Gandhi College.

The total uncertainty in the spectrally dependent AOD by CIMEL sun/sky radiometers and AERONET algorithms is found to be between $\sim 0.01-0.03$ (Holben et al., 2001), with higher errors in the near ultraviolet than in visible range. Further, Dubovik et al. (2000) have shown the accuracy level in the retrieval of SSA, which is of the order of 0.03 for high aerosol loading (AOD $\geq 0.5$ at $440 \mathrm{~nm}$ ) and 0.05 for low aerosol loading ( $\mathrm{AOD} \leq 0.2$ at $440 \mathrm{~nm}$ ). It is notable that, in any case, the retrieval errors are not supposed to exceed $10 \%$ for $0.1 \leq r \leq 7 \mu \mathrm{m}$, and it may increase up to $80 \%$ for fine$(r<0.1 \mu \mathrm{m})$ and coarse- $(r>7 \mu \mathrm{m})$ mode particles. However, it is found that these errors do not significantly affect the important characteristic features of aerosol distribution (Dubovik et al., 2000).

\section{Factors affecting aerosol properties}

\subsection{Topography}

The IGB region is bounded by the Himalayas to the north, and by Vindhyan and Satpura range of mountains in the south. The western part is surrounded by the Thar Desert and Arabian Sea, whereas the eastern part is bounded by the Bay of Bengal. Due to its unique topography, this region can be summarized as a type of region, where, both anthropogenic and natural, aerosols show distinct seasonal characteristics and mixing (Guttikunda et al., 2003; Singh et al., 2004; Monkkonen et al., 2004; Massie et al., 2004; Jethva et al., 2005; Dey et al., 2008; Mishra et al., 2008). General seasonal abundance shows that the winter months are dominated by the fine-mode aerosols, produced by various anthropogenic sources from the IGB region, and pre-monsoon or summer months are dominated by the coarse-mode mineral dust, primarily from the Thar Desert region in the western Rajasthan and its frequent transportation over the IGB region. Further details regarding geography, climate, regional sources and emissions of these aerosols over the IGB as well as over the other Indian region, however, can be found in Ramachandran and Cherian (2008).
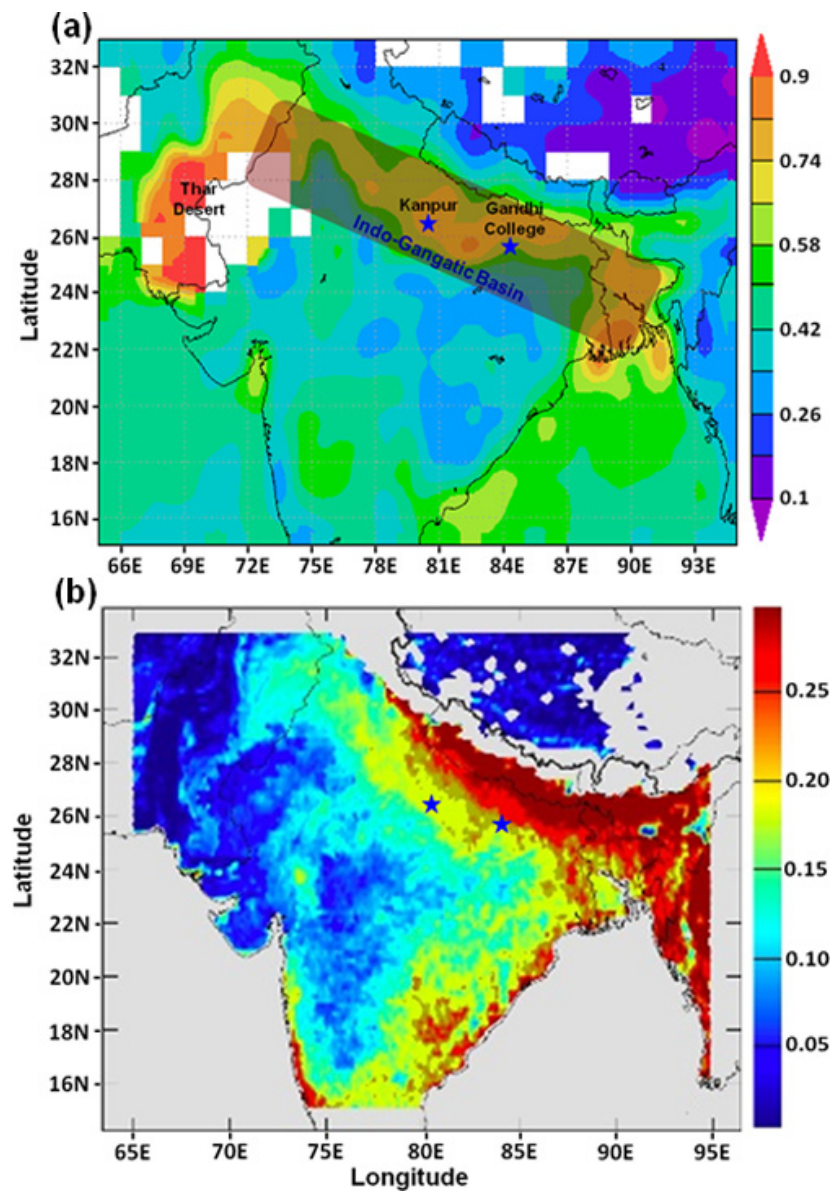

Fig. 1. (a) MODIS AODs at $550 \mathrm{~nm}$ (mean from April to June 2009) showing intense dust loading spreading over the entire IGB, (b) PARASOL fine-mode AODs (mean from April to June 2009) showing significant amount of fine-mode particles over the entire IGB region. The location of measurement sites at the central (Kanpur) and eastern (Gandhi College) part of IGB is marked by blue stars.

\subsection{Synoptic meteorology}

Synoptic meteorology (wind pattern, air temperature and relative humidity) over the stations in the IGB region along with other parts of India and its surroundings are shown in Fig. 2a-c for April to June months of 2009, respectively. National Center for Environmental Prediction (NCEP)-National Center for Atmospheric Research (NCAR) reanalysis monthly data of weather parameters such as wind, air temperature, and relative humidity (RH) at $850 \mathrm{hPa}$ pressure level were used to study the synoptic meteorological conditions over the stations. In Fig. 2a-c, winds are shown with arrows pointing towards the wind direction, where length of arrows defines the magnitude of wind speed (in $\mathrm{m} \mathrm{s}^{-1}$ ), line contour represents air temperature $\left({ }^{\circ} \mathrm{C}\right)$ and shaded color contour represents RH (\%) (showing in purpleblue color for low and red color for high RH). Results reveal 

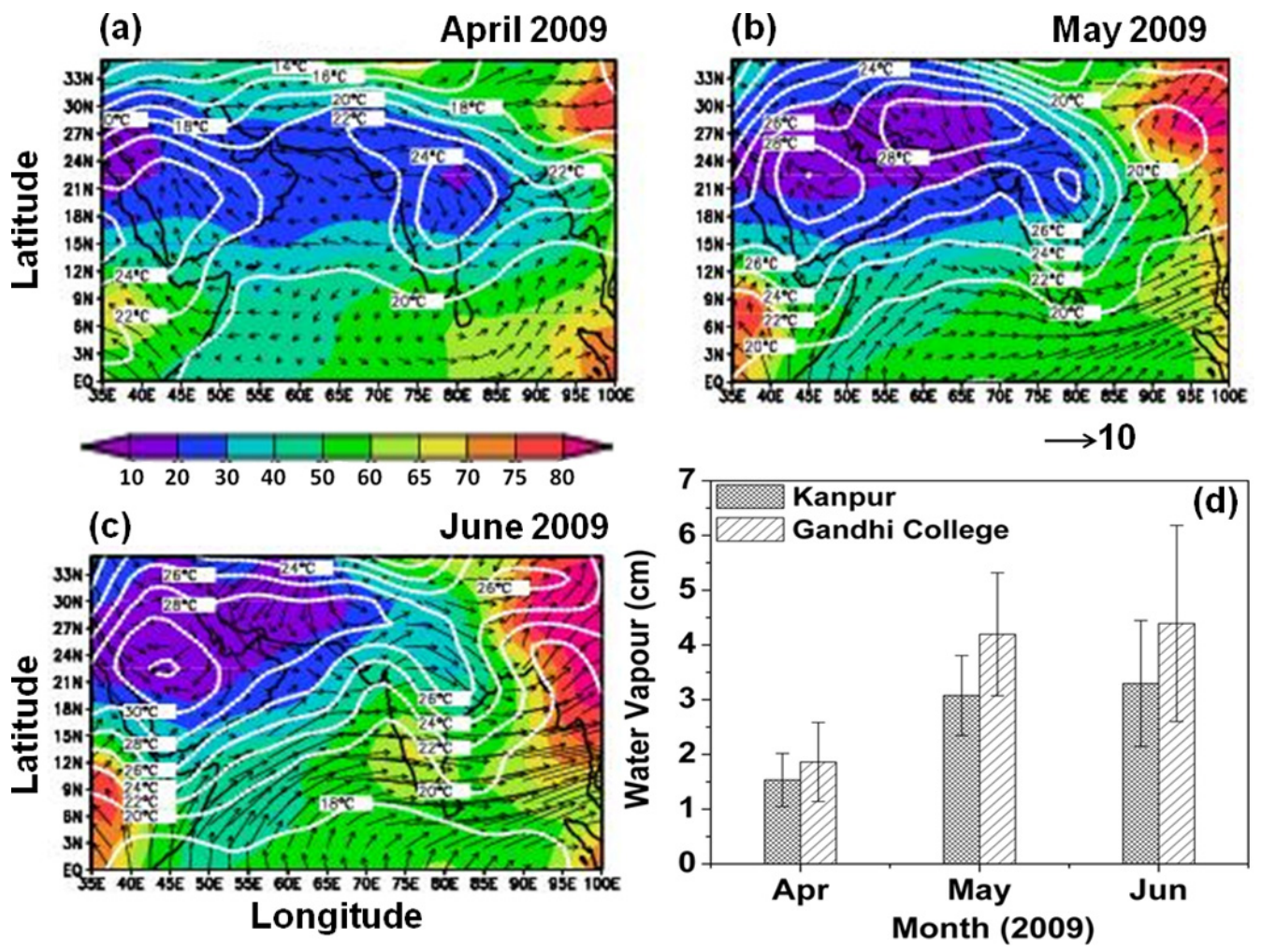

Fig. 2. Synoptic meteorological conditions over the entire IGB region along with the other parts of India and its surroundings during (a) April 2009, (b) May 2009, (c) June 2009 at $850 \mathrm{hPa}$ level and (d) sun photometer retrieved columnar water vapor at Kanpur and Gandhi College during April to June 2009.

that the study regions over IGB are generally characterized by westerly to northwesterly winds during pre-monsoon season, intensifying from April to June months. These winds are found to pass through arid regions of the western India and southwest Asia to bring dry air mass over the stations (Srivastava et al., 2010b). In the year 2009, low air temperature and RH were observed over these stations during April, which was found to be exceeding as months progresses. With the advancement of pre-monsoon from April to June, the west to east temperature gradient is found to increase, to influence the increase of pressure gradient. This pressure gradient caused winds to be intensified from west to eastward locations and from April to June months. These strong winds can carry tremendous amount of mineral dust from the Desert region in the west, and may transport it eastward over the neighboring states of India (Srivastava et al., 2010b). Sun/sky radiometer derived columnar water vapor content at Kanpur and Gandhi College is shown in Fig. 2d. It is found that relatively dry atmosphere exist at both the stations during the month of April, which subsequently got humidified with the advancement of months from May to June. Spatially, higher water vapor content was observed over Gandhi College for all the months in comparison to Kanpur. This observation is well associated with the observed RH over the IGB region during pre-monsoon months.

\subsection{Emission sources}

The IGB region, apart from being a major source region for aerosols, is bordered by densely populated and industrialized areas on the west and eastern sides from where different aerosol species such as mineral dust, soot, nitrate, sulfate particles and organics are produced and transported to this region and thus making it an aerosol hotspot (Ramachandran and Cherian, 2008). The region itself has both, rural and urban, population and various kinds of emission sources, natural as well as industrial. In rural areas, bio-fuels such as fuel wood, dung cake and crop waste, predominantly contribute to aerosol formation (Habib et al., 2006). However, in urban areas, aerosol emissions from fossil fuels such as coal, petrol and diesel oil dominate (Ram and Sarin, 2010; Tiwari et al., 2010). Large fluxes of absorbing aerosol emissions (black carbon and inorganic oxidized matter, which is mostly fly ash from coal-based power plants and particles from open burning of crop waste/forest-fires) were reported over the IGB (Habib et al., 2006). Apart from the dust emissions from the Thar Desert during pre-monsoon months, the influence of emissions from the forest-fires and open burning of crop waste from the central India were also found over IGB during these months as biomass aerosol contribution (Ramachandran and Cherian, 2008). 
Table 1. Mean value ( \pm standard deviation) of aerosol parameters at different stations over IGB region during pre-monsoon.

\begin{tabular}{llcccc}
\hline \multirow{2}{*}{ Month (2009) } & \multirow{2}{*}{ Locations } & \multicolumn{4}{c}{ Mean aerosol parameters } \\
\cline { 3 - 6 } & & $\mathrm{AOD}_{500}$ & $\mathrm{AE}_{440-870}$ & $\mathrm{SSA}_{675}$ & $\mathrm{AP}_{675}$ \\
\hline \multirow{2}{*}{ April } & Kanpur & $0.50( \pm 0.22)$ & $0.49( \pm 0.30)$ & $0.92( \pm 0.02)$ & $0.69( \pm 0.03)$ \\
& Gandhi College & $0.51( \pm 0.20)$ & $0.65( \pm 0.29)$ & $0.88( \pm 0.03)$ & $0.69( \pm 0.03)$ \\
\hline \multirow{2}{*}{ May } & Kanpur & $0.65( \pm 0.12)$ & $0.74( \pm 0.27)$ & $0.91( \pm 0.03)$ & $0.68( \pm 0.02)$ \\
& Gandhi College & $0.67( \pm 0.20)$ & $0.91( \pm 0.34)$ & $0.89( \pm 0.02)$ & $0.67( \pm 0.02)$ \\
\hline \multirow{2}{*}{ June } & Kanpur & $0.69( \pm 0.24)$ & $0.45( \pm 0.27)$ & $0.94( \pm 0.03)$ & $0.70( \pm 0.02)$ \\
& Gandhi College & $0.77( \pm 0.34)$ & $0.71( \pm 0.33)$ & $0.92( \pm 0.03)$ & $0.69( \pm 0.02)$ \\
\hline
\end{tabular}

The IGB covers $\sim 20 \%$ geographical area and contributes $\sim 42 \%$ to the total food grains production of India and holds nearly $\sim 40 \%$ of the total population (Tripathi et al., 2005). In the IGB region, $\sim 12$ million hectares is accounted for ricewheat crop rotation. Harvesting of these crops with combine harvesters is very popular with the farmers (Badarinath et al., 2009). Harvesting of wheat system is usually done during pre-monsoon mainly in the months of May and June, which leaves behind large quantities of straw in the field as crop residues. These crop residues are subjected to open burning to clear the wastes and to prepare the field for sowing the rice system, which generate abundance of biomass aerosols (fine-size) over the region during pre-monsoon period.

\section{Results and discussion}

\subsection{Optical and microphysical properties of aerosol}

\subsubsection{Aerosol optical depth and Angstrom exponent}

Figure 3a shows daily mean variations in AOD (at $500 \mathrm{~nm}$ ) at Kanpur and Gandhi College, respectively, during April to June 2009. A consistent increase in the magnitude of AOD, ranging from 0.21 (April) to 1.30 (June) at Kanpur and 0.22 (April) to 1.53 (June) at Gandhi College was observed. Angstrom exponent (AE), derived from the spectral dependence of AOD measurements, computed for the wavelength pair of 440 and $870 \mathrm{~nm}$, is shown in Fig. 3b for the two stations. The AE is supposed to provide qualitative approximation about the dominant size of the particles, with higher AE implying dominance of small-size particles and vice-versa (Srivastava et al., 2008). Changes in the size of fine-mode concentrations are possible due to coagulation, which increases with increasing aerosol loading under suitable meteorological conditions (Eck et al., 2005, 2010; Li et al., 2007). The observed large range of AE, from 0.06 to 1.19 at Kanpur and 0.15 to 1.37 at Gandhi College, suggests that there are different types of aerosols (from coarse-mode dust to fine-mode pollution) present over these stations during pre-monsoon, caused by day-to-day variations in the weather parameters and emission factors. An increase in AOD with corresponding increase in $\mathrm{AE}$, which is the case observed at Gandhi College, suggests an enhancement in fine-mode particles over the station. Results are expected to be caused due to open burning of field straw of wheat harvest, which is usually done in the northern India during the pre-monsoon and generated abundance of fine-mode biomass aerosols over the region (Badarinath et al., 2009; Sharma et al., 2010).

Monthly mean values of AOD and AE, calculated by daily means for April, May and June 2009 at both the considered stations are given in Table 1. A gradual increase in AOD was observed at both the stations with the advancement of the pre-monsoon season, from April to June, which was found to be slightly higher at Gandhi College than observed at Kanpur. A small positive gradient in AOD was observed from Kanpur to Gandhi College when AOD at Kanpur was found to be low by $\sim 2 \%, 4 \%$ and $10 \%$ from the values observed at Gandhi College during April, May and June months, respectively. The increasing AOD from Kanpur to Gandhi College is expected due to increased aerosol loading from natural and/or anthropogenic origin. Though Gandhi College (Ballia) is much smaller station than the city like Kanpur, it is one of the representative rural AERONET sites, which is affected mostly by the fine-size aerosols rather than the coarse-size dust aerosols. These results are substantiated by the air mass back-trajectory analysis given in the Sect. 4.1.3.

Besides day-to-day variability in $\mathrm{AE}$, it can be seen that both stations are influenced by dust loading because of mean $\mathrm{AE}<1$ (Eck et al., 2010); however, Gandhi College is relatively dominated by anthropogenic aerosols (mostly from biomass), mainly during the month of May. A gradual increase in the magnitude of $\mathrm{AE}$ was observed at both the stations during April to May, which is found to decrease during the month of June (Table 1). However, relatively large magnitude of AE was found over Gandhi College as compare to Kanpur during pre-monsoon, indicating large influence of fine-size particles in AOD at Gandhi College. On the other hand, relatively low $\mathrm{AE}$ at Kanpur informs dominance of coarse-mode dust particles in AOD, which are mostly transported from the nearby Thar Desert region in the western 
Table 2. Mean volume size distribution parameters of aerosol particles* at different stations over IGB region during pre-monsoon.

\begin{tabular}{llcccccccc}
\hline \multirow{2}{*}{ Month (2009) } & \multirow{2}{*}{ Locations } & \multicolumn{7}{c}{ Aerosol parameters of volume size distribution } \\
\cline { 3 - 9 } & & $V_{\mathrm{f}}$ & $R_{\mathrm{eff}, \mathrm{f}}$ & $V M R_{\mathrm{f}}$ & $\sigma_{\mathrm{f}}$ & $V_{\mathrm{c}}$ & $R_{\mathrm{eff}, \mathrm{c}}$ & $V M R_{\mathrm{c}}$ & $\sigma_{\mathrm{c}}$ \\
\hline \multirow{2}{*}{ April } & Kanpur & 0.04 & 0.12 & 0.14 & 0.53 & 0.32 & 2.25 & 2.80 & 0.64 \\
& Gandhi College & 0.05 & 0.12 & 0.13 & 0.47 & 0.28 & 2.38 & 2.95 & 0.62 \\
\hline \multirow{2}{*}{ May } & Kanpur & 0.07 & 0.12 & 0.13 & 0.47 & 0.34 & 2.13 & 2.63 & 0.63 \\
& Gandhi College & 0.09 & 0.14 & 0.15 & 0.46 & 0.23 & 2.06 & 2.57 & 0.65 \\
\hline \multirow{2}{*}{ June } & Kanpur & 0.05 & 0.11 & 0.13 & 0.56 & 0.49 & 2.18 & 2.65 & 0.59 \\
& Gandhi College & 0.08 & 0.13 & 0.14 & 0.49 & 0.32 & 2.16 & 2.63 & 0.61 \\
\hline
\end{tabular}

${ }^{*} V_{\mathrm{f}}$ and $V_{\mathrm{c}}$ are the volume concentration (in $\mu \mathrm{m}^{3} \mu \mathrm{m}^{-2}$ ) of fine and coarse particles, respectively; $R_{\text {eff,f }}$ and $R_{\text {eff,c }}$ are the effective radii (in $\mu \mathrm{m}$ ) of fine- and coarse-modes, respectively; $\mathrm{VMR}_{\mathrm{f}}$ and $\mathrm{VMR}_{\mathrm{c}}$ are the volume median radius (in $\mu \mathrm{m}$ ) of fine- and coarse-modes, respectively and $\sigma_{\mathrm{c}}$ and $\sigma_{\mathrm{f}}$ are the geometric standard deviation of fine- and coarse-modes, respectively.

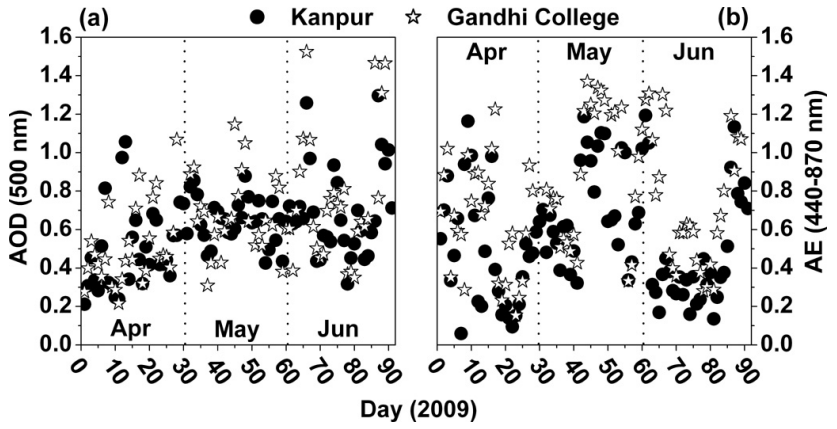

Fig. 3. Daily mean variations in (a) $A O D$ at $500 \mathrm{~nm}$ and (b) $\mathrm{AE}$ at $440-870 \mathrm{~nm}$ at Kanpur and Gandhi College during April to June 2009.

Rajasthan. This fact is also reported by various authors as one of the major dust source region over IGB during premonsoon (Dey et al., 2004; Singh et al., 2005; Pandithurai et al., 2008; Srivastava et al., 2010c). As month advances from April to June, a positive gradient in the magnitude of $\mathrm{AE}$ as seen in AOD, is evident from Kanpur to Gandhi College implies spatial changes in aerosol features over IGB region during the study period. In order to substantiate the above results, fine- and coarse-mode aerosol fractions, derived from sun/sky radiometer, have been examined for these stations (not shown here). As expected, fine-mode fraction was found to be relatively higher $(\sim 27 \%)$ at Gandhi College and coarse-mode fraction was found to be relatively higher ( $20 \%)$ at Kanpur. A small gradient from Kanpur to Gandhi College was observed in both fine- and coarse-mode fractions, which was positive for fine-mode and negative for coarse-mode fraction, and suggests an increase in fine-size particles over the eastern IGB (Gandhi College) and coarsesize over the central IGB (Kanpur) region.

\subsubsection{Aerosol volume size distribution}

Sun/sky radiometer retrieves aerosol volume size distribution for 22 size bins between 0.05 and $15 \mu \mathrm{m}$. Such distributions are depicted in Fig. 4a-c for Kanpur and Gandhi College from April to June 2009. It was found that they follow bi-modal size distributions at both the stations during all the considered months; however, they show different volume concentrations, and effective radius in fine- and coarse-sizes to the earlier reported values (Singh et al., 2004; Prasad et al., 2007; Pandithurai et al., 2008) over the IGB region. The observed bi-modal size distributions can be explained on the basis of mixing of air masses containing primary aerosols with fine- and coarse-modes (Hoppel et al., 1985) or heterogeneous nucleation and growth of particle size by condensation of gas phase reaction products (Dey et al., 2004). It can be seen from Fig. $4 \mathrm{a}-\mathrm{c}$ that the volume concentration in fine-size is comparatively larger and coarse-size is smaller at Gandhi College than Kanpur. The difference in fine- and coarse-size aerosol volume concentrations at both stations are more pronounced during the month of June. A small positive shift in the magnitude of fine-size aerosol volume concentration was observed from Kanpur to Gandhi College during almost all the months, which is more pronounced during the month of June. Results could be due to the possible hygroscopic growth of fine-size particles at Gandhi College with higher RH, as can be seen clearly with the spatial distribution of RH during the month of June in Fig. 2c. The fine-size particles were observed to be ranging from about $0.1-0.2 \mu \mathrm{m}$ and coarse-size particles from about $3-4 \mu \mathrm{m}$ at both the stations during pre-monsoon.

Monthly mean aerosol volume size distribution parameters such as columnar volume concentration $(V)$, effective radii ( $\left.R_{\text {eff }}\right)$, volume median radius (VMR) and geometric standard deviation $(\sigma)$ for fine (f)- and coarse (c)-modes at Kanpur and Gandhi College are presented in Table 2. It is noted from Table 2 that the magnitude of volume concentration in fine-mode $\left(V_{\mathrm{f}}\right)$ is higher at Gandhi College as compared to 


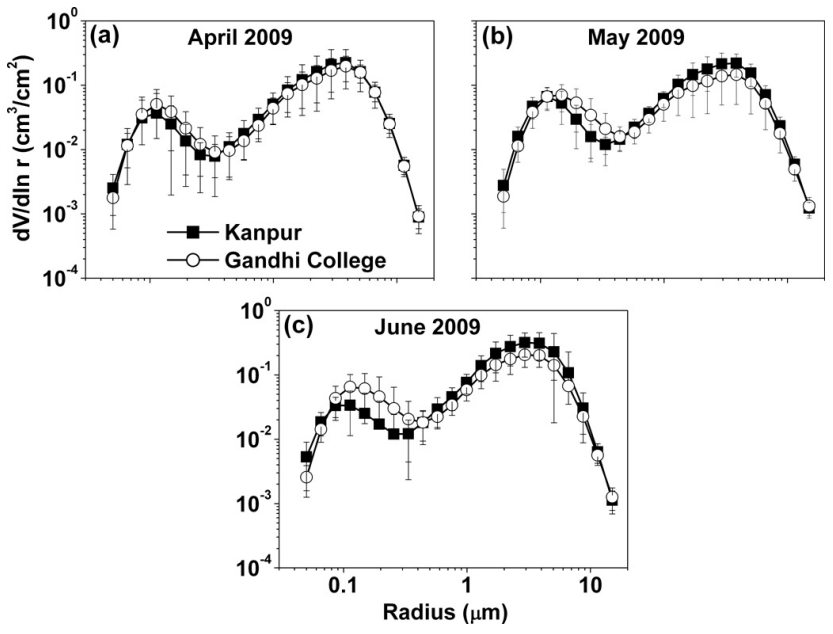

Fig. 4. Aerosol volume size distribution for 22 size bins between 0.05 and $15 \mu \mathrm{m}$ at Kanpur and Gandhi College during (a) April 2009, (b) May 2009 and (c) June 2009. The vertical bars at each size bin indicate standard deviation (SD) from their mean.

Kanpur; however, vice-versa was observed for the volume concentration in coarse-mode $\left(V_{\mathrm{c}}\right)$ at these stations. Results confirm the relative dominance of fine-mode particle concentrations at Gandhi College and coarse-mode at Kanpur with no significant changes in the mean effective radius for fine-mode particle size $\left(R_{\text {eff,f }}\right)$ at these stations during premonsoon. However, changes in the mean effective radius for coarse-mode particle $\left(R_{\text {eff,c }}\right)$ was observed at both the stations during each considered months of pre-monsoon. Results suggest large variability in the coarse particle sources; however, the fine particle sources are by-and-large stable at both the stations over the IGB.

\subsubsection{Air mass back-trajectory analysis}

Since the impact of ambient aerosols on radiation budget of the atmosphere changes with source regions and transport pathways, it is prerequisite to get the information for their impact assessment. In order to know the transport pathways, 5-day backward air mass trajectories have been computed using the Hybrid Single Particle Lagrangian Integrated Trajectory (HYSPLIT) model of the National Oceanic and Atmospheric Administration (NOAA), USA (Draxler and Rolph, 2003). Figure $5 \mathrm{a}-\mathrm{c}$ shows mean backward-trajectories from two stations for the month of April to June 2009 to locate the path of transport of dust-carrying air masses to each station at an altitude of $1000 \mathrm{~m}$ above mean sea level (a.m.s.l.). It is evident from Fig. 5 that there are different pathways for the transport of air masses from the source regions to both the stations during different months.

Figure 5a shows that the air masses reaching to each station over the IGB region during April month are mostly started 5-days back from the Gulf regions, and have longer and wider spread of pathways at Kanpur as compare to Gandhi College where nearly similar air mass pathway was observed with relatively narrow spreading. Figure $5 \mathrm{~b}$ shows comparatively larger spreading of air mass pathway at Gandhi College than at Kanpur during the month of May, indicating large variability in the transport of air mass at Gandhi College. Figure 5c shows that during the month of June, air masses are mostly confined over the Thar Desert region, and transported at Kanpur, whereas for Gandhi College, back-trajectories show that the air mass is highly localized and confined to the IGB region only. Results show that, except during the month of June, air masses reaching at Gandhi College follow the similar path as air masses reaching at Kanpur. There may be the possibility of mixing of air masses reaching at Gandhi College with the air masses already arrived at Kanpur during April and May months, depending upon the initial and final altitudes of these air masses at both the stations. Figure 5d depicts air mass altitude variations with back-days at Kanpur (with solid lines) and Gandhi College (with dotted lines) during April to June. Final altitude for the backward air mass trajectory is 775 and $535 \mathrm{~m}$ above the ground level (a.g.l.), respectively at Kanpur and Gandhi College (corresponds to $1000 \mathrm{~m}$ a.m.s.l. altitude at both the stations). It is evident from the figure that except in the month of June, air masses at both the stations are arriving from the higher attitudes. Also, air masses reaching at Gandhi College during all the months are mixed with the air masses that already affected Kanpur, as shown by the interaction of air masses at different altitudes (shown by circles in Fig. 5d). Thus, the eastern IGB region, apart from the local aerosol sources, could also be influenced by the aerosol particles carrying from the other parts of the IGB and the surrounding Desert regions. However, during June, Gandhi College is largely influenced by the locally generated aerosols only. Similar information is also observed in the wind pattern of June month (Fig. 2c), which shows intensification in the wind speed from west-northwest to southeast direction over the IGB region.

\subsection{Radiative properties of aerosol}

\subsubsection{Single scattering albedo}

Aerosol single scattering albedo (SSA), characterizes the combined effect of scattering and absorption properties of aerosols. The scattering and absorption characteristics of different aerosol types in combination with surface reflectance determine whether the aerosol is contributing to cooling or heating (Satheesh, 2002). In addition, it is a measure of the fraction of radiation absorbed by atmospheric aerosols (expressed through 1-SSA). Monthly mean SSA retrieved by sun/sky radiometer at $675 \mathrm{~nm}$ is also shown in Table 1 for Kanpur and Gandhi College stations during April-June. Though, average SSA was observed to be more than 0.85 at both the stations over IGB, it was found to be relatively lower 

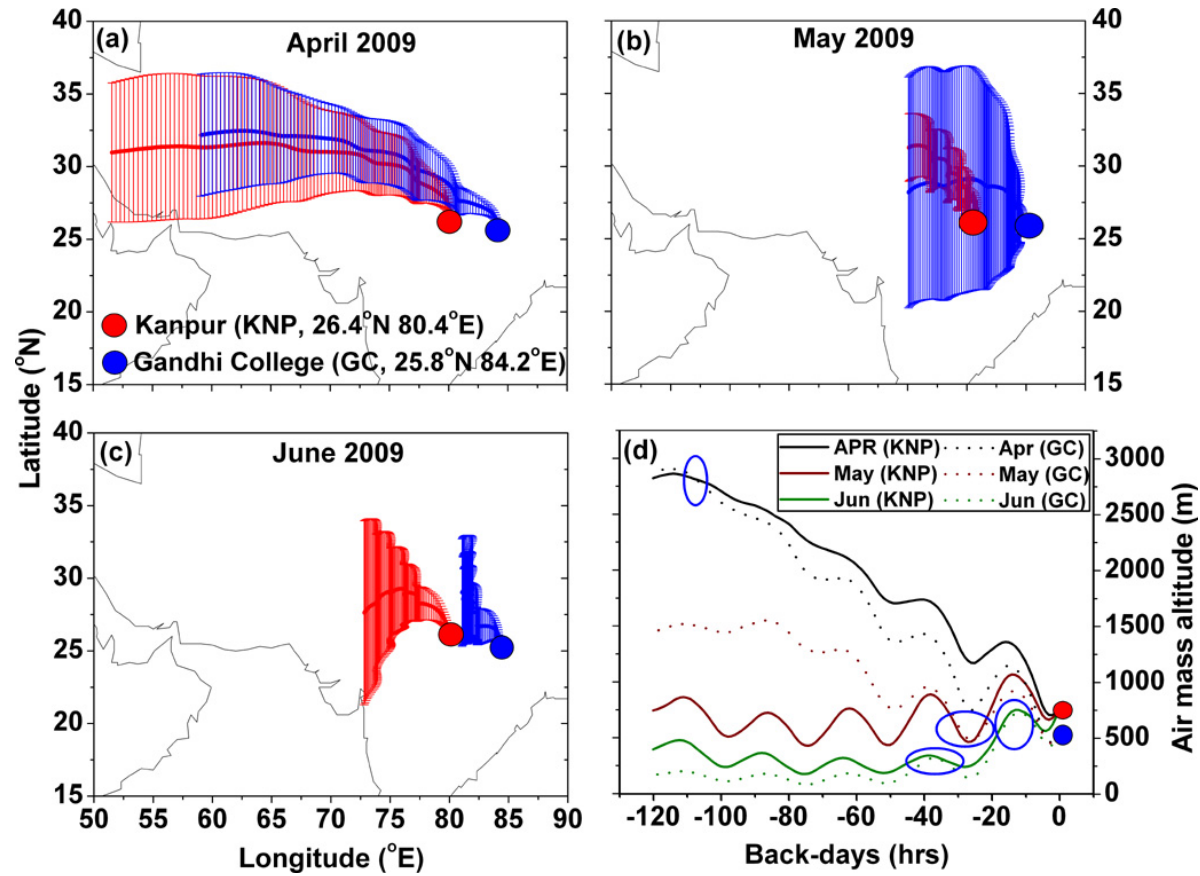

Fig. 5. 5-day air mass back-trajectory clusters at Kanpur and Gandhi College during (a) April 2009, (b) May 2009 and (c) June 2009 (vertical lines show standard deviations, represent spreading of air masses). (d) Air mass altitude variations with back-days at Kanpur (KNP, with solid lines) and Gandhi College (GC, with dotted lines) during April to June.

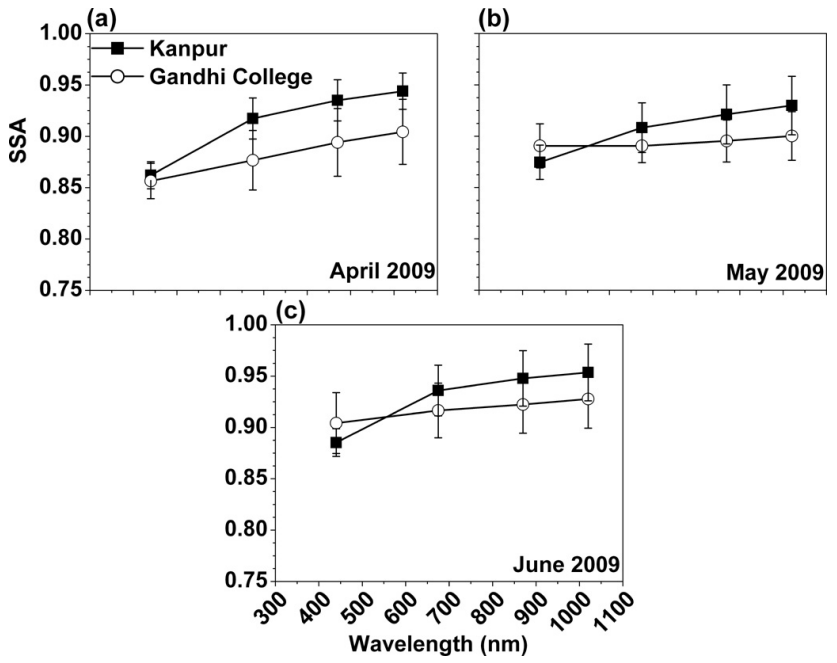

Fig. 6. Spectral variations of SSA at four discrete wavelengths $(440,675,880$ and $1020 \mathrm{~nm})$ at Kanpur and Gandhi College during (a) April 2009, (b) May 2009 and (c) June 2009.

at Gandhi College (0.89) than observed at Kanpur (0.92) during the pre-monsoon period. Results suggest dominance of absorbing type aerosols at Gandhi College in comparison to Kanpur. The observed SSA at both the stations over the IGB region is found to be by-and-large comparable with the earlier reported values over IGB during pre-monsoon period
(Singh et al., 2004; Prasad et al., 2007; Dey and Tripathi, 2008; Pandithurai et al., 2008; Srivastava et al., 2010c). Constructing the aerosol compositions by combining two different aerosol types (urban and desert) during pre-monsoon period, Singh et al. (2010) have derived SSA value at the nearby station at New Delhi over the IGB region, which was found to be $\sim 0.80$ at $500 \mathrm{~nm}$. In other studies, Pandithurai et al. (2008) have reported SSA (at $500 \mathrm{~nm}$ ) at New Delhi in the range between 0.74 and 0.84 during pre-monsoon. However, Srivastava et al. (2010c) have reported comparatively larger value of SSA $(\sim 0.94 \pm 0.04$ at $675 \mathrm{~nm})$ during the month of June, which could be due to the presence of higher loading of water-soluble aerosols produced from the anthropogenic sources nearby the station (Singh et al., 2004; Prasad et al., 2007).

The mean spectral variations of SSA at four discrete wavelengths $(440,675,870$ and $1020 \mathrm{~nm})$ for both the stations during the months of April, May and June are shown in Fig. 6a-c, respectively. Interesting features were observed, which are: (i) large spectral dependence (i.e. SSA increase with increasing wavelength) was observed at Kanpur, indicating relative dominance of dust as also reported earlier for various episodes of dust advection over the IGB region (Dey et al., 2004; Singh et al., 2005, 2010; Pandithurai et al., 2008; Srivastava et al., 2010c), (ii) relatively less spectral dependence was observed at Gandhi College, exhibits the dominance of biomass burning generated aerosols along with transported urban-industrial aerosols from fossil 
fuel combustion from nearby and far located regions, and (iii) spectral variation in SSA at Gandhi College in the month of April shows nearly similar feature (large spectral dependence) as observed at Kanpur for dust-containing aerosols; however, its magnitude was found to be relatively low at Gandhi College than Kanpur for all the considered wavelengths. Singh et al. (2004) at Kanpur and Pandithurai et al. (2008) as well as Srivastava et al. (2010c) at New Delhi have reported similar kind of SSA spectra for dust-containing aerosols during pre-monsoon as absorption due to dust is much higher at the lower wavelengths which rapidly decreases in the higher wavelengths (Dey and Tripathi, 2008). Bergstrom et al. (2007) and Russell et al. (2010) have shown spectra of aerosol SSA at different regions of the world and used the information to infer the compositions of various types of aerosols presence for various locations. They have reported that the SSA spectra increases with increasing wavelength for desert dust dominated locations, similar to the case at Kanpur in the present study. They further reported that the locations dominated by the urban-industrial and biomass burning aerosols show the SSA spectra to decrease with increasing wavelength, but, such spectra was not observed in the present study at Gandhi College probably due to mixing of these aerosols with the locally generated dust aerosols.

Following the Bergstrom et al. (2007) and Russell et al. (2010), the spectral absorption aerosol optical depth (AAOD) at both the stations during pre-monsoon period is obtained as

$$
\operatorname{AAOD}(\lambda)=[1-\operatorname{SSA}(\lambda)] \operatorname{AOD}(\lambda)
$$

where $\lambda$ is the wavelength. This is a well known theoretical equation, which provides information about the absorbing optical properties of aerosols with the term 1-SSA $(\lambda)$, representing the fraction radiation absorbed by atmospheric aerosols.

The AAOD follows a decrease with increasing wavelength at both the stations during each month (Fig. 7a-c) having relatively larger slope at Kanpur than Gandhi College. The absorption Angstrom exponent (AAE) is computed from the slope of spectral absorption optical depth in the wavelength range from 440 to $1020 \mathrm{~nm}$ (corresponds to the retrieved SSA values used for AAOD calculation), which is analogues to the Angstrom power law (Ångström, 1964).

The magnitude of AAE at each station in each month is shown by the arrows in Fig. 7a-c and the same is plotted in Fig. 7d, separately. An enhancement over AAE value of 1.0, a theoretical AAE value for black carbon (Bergstrom et al., 2007), was found at both the stations. Results suggest the absorption could be due to the presence of mineral dust and biomass burning aerosols at both the locations over the IGB region during pre-monsoon period, in which dust aerosols absorption is mostly dominating at Kanpur $(\mathrm{AAE}=1.62)$ and biomass aerosols absorption is mostly dominating at Gandhi College $(\mathrm{AAE}=1.46)$. Similar to SSA, a negative
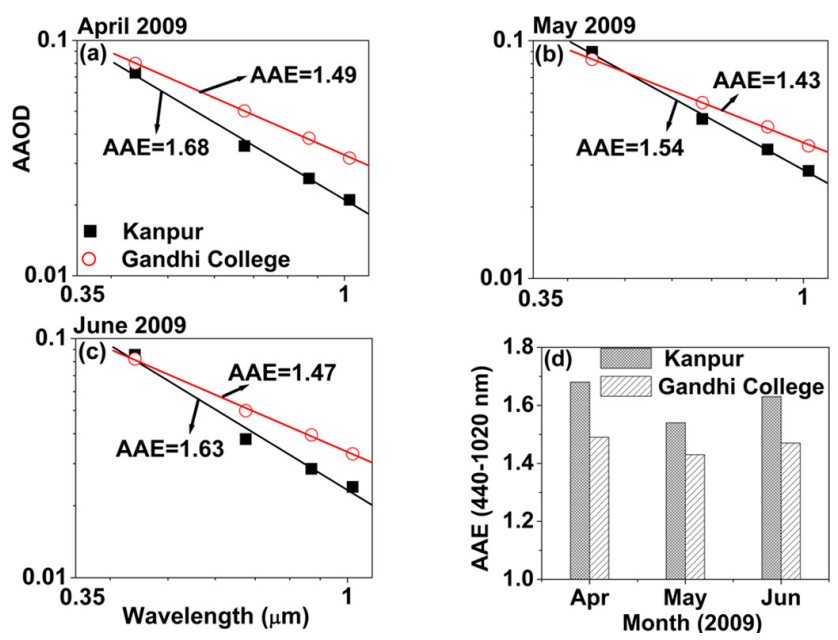

Fig. 7. The absorption aerosol optical depth (AAOD) versus wavelength for Kanpur and Gandhi College during (a) April 2009, (b) May 2009 and (c) June 2009. The curve fit straight line represents the best-fit absorption Angstrom exponent (AAE) shown by arrows. (d) AAE for the wavelength region of 440-1020 nm at Kanpur and Gandhi College during April to June 2009.

gradient in the magnitude of AAE was observed from Kanpur to Gandhi College during pre-monsoon. It is expected from the results that the atmospheric absorption over the central IGB (Kanpur) region could mainly be due to dominance of coarse-mode dust particles, transported from the Thar Desert region and their mixing/coating with polluted aerosols. On the other hand, over the eastern IGB (Gandhi College) region, the atmospheric absorption could be expected mostly due to dominance of fine-particles from biomass burning along with locally produced coarse-dust particles. Earlier, Collaud et al. (2004) measured the scattering and absorption wavelength dependence during Saharan dust events at the Jungefraujoch station, and informed that the AAE of the Saharan dust particles increased from above 1.0 to a range between 1.0 and 2.0. Results are highly associated with the steepness of the slope of AAOD with the wavelength as shown in Fig. 7a-c and the variations in monthly mean SSA.

\subsubsection{Asymmetry parameter}

The asymmetry parameter (AP), i.e. angular distribution of light scattering by the aerosol particles, is an important property of aerosol, which actually regulates the aerosol radiative forcing. The ideal value of AP ranges from -1 (for entirely backscattered radiation) to +1 (for entirely forward-scattered radiation). Similar to SSA, this parameter is also dependent on the size and the composition of particles (Andrews et al., 2006; Ramachandran and Rajesh, 2008). The monthly mean values of AP during April-June retrieved by sun/sky radiometer at $675 \mathrm{~nm}$ are given in Table 1 for Kanpur and Gandhi College. Small negative gradient in the magnitude 


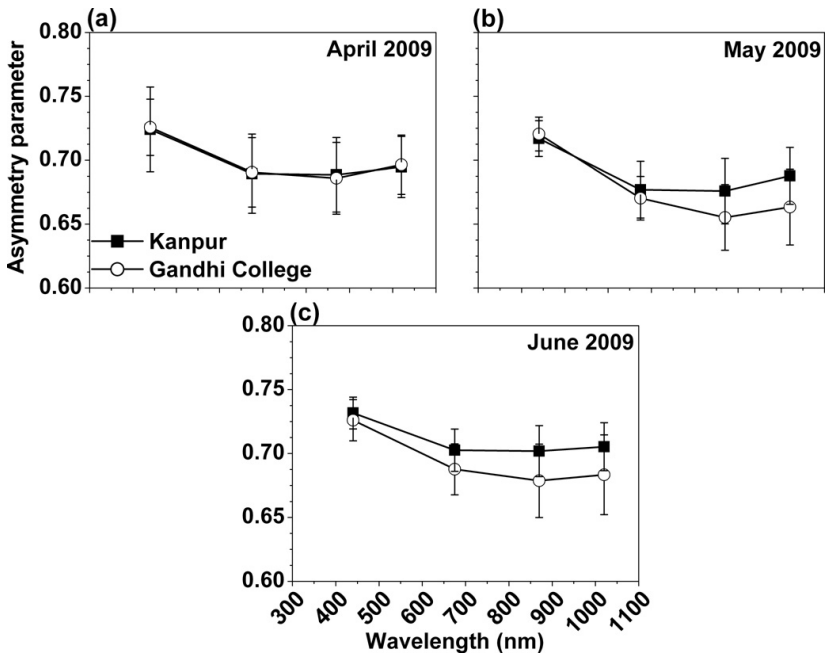

Fig. 8. Same as Fig. 6 for AP at four discrete wavelengths (440, $675,880$ and $1020 \mathrm{~nm})$.

of AP was observed, in concurrence with SSA, from Kanpur to Gandhi College almost in each month except during the month of April, when the magnitude was found to be almost equal. Results suggest a gradient of coarse-to-finemode particles over the IGB region. Results also show that AP is behaving opposite to the variations in AE (Table 1), and indicate a decrease in the magnitude of AP with increasing $\mathrm{AE}$ values, and vice-versa, at both the stations during pre-monsoon period.

Ramachandran and Rajesh (2008) have derived AP values for the coastal stations in India and given a range of 0.3 to 0.6 at $550 \mathrm{~nm}$ for coastal aerosols. However, D'Almeida et al. (1991) suggested the range of AP between 0.64 and 0.83 (average 0.72 ) for dry aerosol particles at $500 \mathrm{~nm}$ depending on the aerosol type and seasonal variability. Andrews et al. (2006) reported the values of AP at $550 \mathrm{~nm}$ between 0.60 $( \pm 0.03)$ for dry aerosols to $0.65( \pm 0.05)$ for aerosols at ambient conditions. The mean spectral variations of AP at four discrete wavelengths for two stations over IGB region during April, May and June are shown in Fig. 8a-c, respectively. The magnitude of AP was found to decrease with increasing wavelength in the visible region and an increase in the near-IR region at all stations in each month, which may be attributed to the presence of coarse-size dust particles during pre-monsoon. This feature was seen prominent at Kanpur during all the months as compare to Gandhi College.

\subsection{Aerosol radiative forcing}

Aerosol radiative forcing is defined as the net change of topof-atmosphere (TOA)/surface radiative flux due to aerosols. In the present analysis, net radiative flux has been estimated in the short-wave region $(0.25-4.0 \mu \mathrm{m})$ with and without aerosols at TOA and at the surface using the Santa Barbara
DISORT Atmospheric Radiative Transfer (SBDART) model (Ricchiazzi et al., 1998). The basic input parameters used in the SBDART for forcing estimations are spectral AOD, SSA and AP. Besides these, other important input parameters includes solar geometry, model atmospheric profile and the surface albedo. The information on vertical distribution of aerosols is of paramount importance and a major source of uncertainty in the estimation of atmospheric radiative forcing (Ganguly et al., 2009; Lemaitre et al., 2010). In most of the studies, surface aerosol properties are attributed to the column properties by making assumptions about the vertical profiles. However, in the present study, sun/sky radiometer derived columnar aerosol parameters at different wavelengths were used in the estimation of radiative forcing.

Based on the measured meteorological parameters and prevailing atmospheric conditions, the tropical model atmospheric profile has been used in the present case. In order to have a better representation of the atmosphere and the accuracy of the estimated aerosol radiative forcing, monthly mean value of columnar water vapor, retrieved by the sun/sky radiometer $\left(1.5\right.$ and $1.8 \mathrm{~g} \mathrm{~cm}^{-2}$ during April, 3.0 and $4.1 \mathrm{~g} \mathrm{~cm}^{-2}$ during May and 3.2 and $4.3 \mathrm{~g} \mathrm{~cm}^{-2}$ during June, respectively for Kanpur and Gandhi College) and total column ozone retrieved by Ozone Monitoring Instrument (OMI) onboard Aura spacecraft (278 and 279 DU during April, 286 and 287 DU during May and 278 and 284 DU during June, respectively, for Kanpur and Gandhi College) were used in SBDART model. Since surface albedo plays a crucial role in the forcing estimations, it was obtained at each station during the months from April to June 2009 from the Aura OMI version 3 reflectivity data (at $500 \mathrm{~nm}$ wavelength). The surface albedo for each month at each station is obtained by averaging the values of each day in the particular month. The monthly mean surface albedo values at single wavelength (at $500 \mathrm{~nm}$ ) were obtained about 0.12 and 0.13 in April, 0.19 and 0.22 in May and 0.21 and 0.23 in June at Kanpur and Gandhi College, respectively. In a recent study, Raut and Chazette (2008) have discussed the influence of spectral surface albedo values on radiation budget. There are some differences in surface albedo values found in the present study at both the stations, having relatively higher values at Gandhi College as compare to Kanpur during premonsoon. However, the magnitude of surface albedo was found to be increased with the advancement of pre-monsoon months at both the stations. Calculations of irradiance were repeated for every $5^{\circ}$ solar zenith angle and the diurnally averaged radiative forcing were estimated for the TOA and surface. The difference between the TOA and surface forcing is considered as atmospheric forcing $(\Delta F)$, which represents the amount of energy trapped within the atmosphere by absorbance of the aerosols to get transformed into heat.

Figure $9 \mathrm{a}-\mathrm{c}$ shows short-wave radiative forcing at the TOA, surface and in the atmosphere, respectively, at Kanpur and Gandhi College over the IGB region during premonsoon. TOA forcing was found to be negative during all 


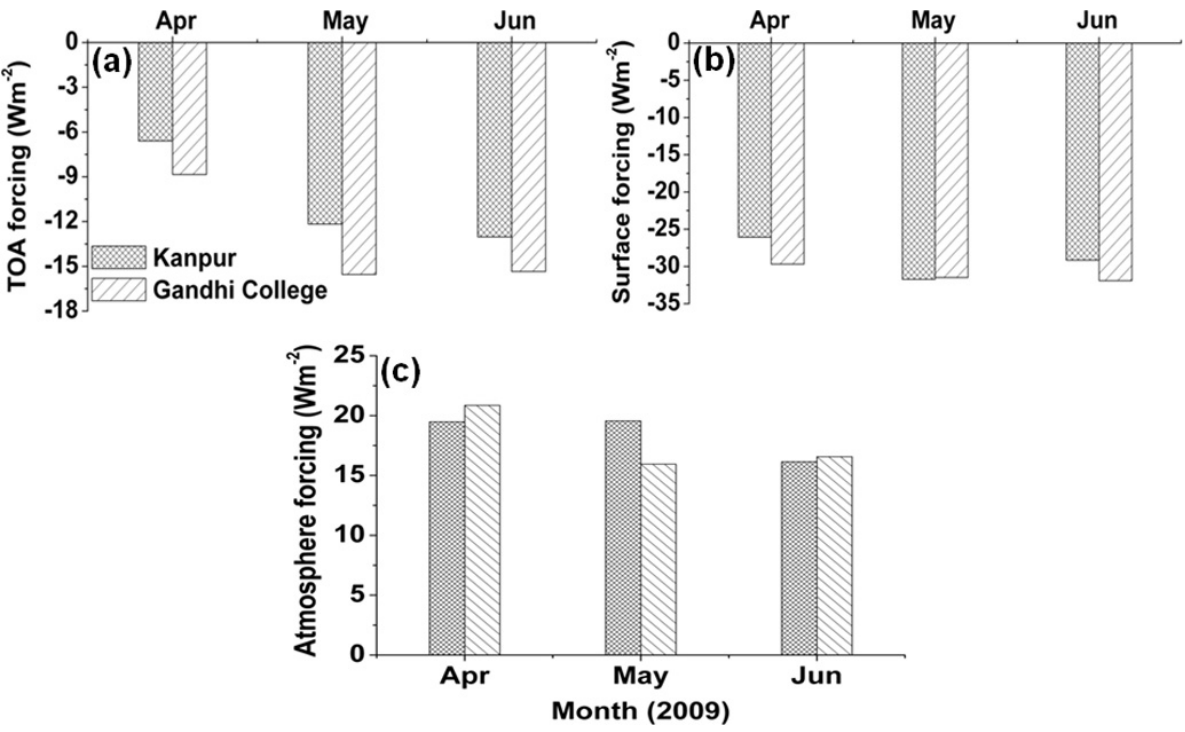

Fig. 9. Short-wave radiative forcing at (a) TOA, (b) surface and (c) in the atmosphere at Kanpur and Gandhi College during April to June 2009.

the months at both the stations indicating net cooling. The monthly mean TOA forcing (Fig. 9a) was found to be -6.6 and $-8.9 \mathrm{~W} \mathrm{~m}^{-2}$ during April, -12.2 and $-15.5 \mathrm{~W} \mathrm{~m}^{-2}$ during May and -13.0 and $-15.4 \mathrm{~W} \mathrm{~m}^{-2}$ during June at Kanpur and Gandhi College, respectively. On the other hand, surface forcing (Fig. 9b), which is the net flux received at the surface after passing through the atmosphere, was also observed to be negative at both the stations during all the months. The monthly mean surface forcing was observed to be about -26.1 and $-29.7 \mathrm{~W} \mathrm{~m}^{-2}$ during April, -31.7 and $-31.5 \mathrm{~W} \mathrm{~m}^{-2}$ during May and -29.2 and $-31.9 \mathrm{~W} \mathrm{~m}^{-2}$ during June at Kanpur and Gandhi College, respectively. The resultant atmospheric forcing (difference between TOA and surface forcing) is the absorption due to aerosols within the atmosphere, which is shown in Fig. 9c for both the stations during pre-monsoon. Atmospheric forcing was found to be +19.5 and $+20.9 \mathrm{~W} \mathrm{~m}^{-2}$ during April, +19.6 and $+16.0 \mathrm{~W} \mathrm{~m}^{-2}$ during May and +16.1 and $+16.6 \mathrm{~W} \mathrm{~m}^{-2}$ during June at Kanpur and Gandhi College, respectively, and indicates significant heating of the atmosphere at both the stations. An interesting feature in radiative forcing was observed during May month when surface forcing was found to be by-and-large equal at both the stations. On the same period, TOA forcing at Gandhi College was found to be relatively larger (more negative) than at Kanpur (less negative), which was opposite for atmospheric forcing at these stations. Results indicate that relatively large heating was exerted into the atmosphere at Kanpur as compare to Gandhi College during May due to dominance of dust absorption. Computed forcing efficiency (i.e. the change in net flux $[\Delta F]$ at the surface or TOA per unit AOD at $500 \mathrm{~nm}$ ) at the surface was found to be about -21 and $-9 \mathrm{~W} \mathrm{~m}^{-2}$ and at the TOA, it was about -34 and $-26 \mathrm{~W} \mathrm{~m}^{-2}$ during pre-monsoon period for Kanpur and Gandhi College, respectively.

Large aerosol induced negative surface forcing (more than $-20 \mathrm{~W} \mathrm{~m}^{-2}$ ) with higher values (more than $-30 \mathrm{~W} \mathrm{~m}^{-2}$ ) during the pre-monsoon season was reported by Dey and Tripathi (2008) at Kanpur with negative TOA forcing, when the transported natural dusts get mixed with anthropogenic aerosol pollution. Moreover, Prasad et al. (2007) have reported a change in the average surface forcing by about $-23 \mathrm{~W} \mathrm{~m}^{-2}$ and in the TOA forcing by about $-11 \mathrm{~W} \mathrm{~m}^{-2}$ during dusty days as compared to the non-dusty days (pre-monsoon season). On the other hand, Pandithurai et al. (2008) have observed a consistent increase in surface cooling, ranging from -39 (March) to $-99 \mathrm{~W} \mathrm{~m}^{-2}$ (June) and an increase in heating of the atmosphere from $+27 \mathrm{~W} \mathrm{~m}^{-2}$ (March) to $+123 \mathrm{~W} \mathrm{~m}^{-2}$ (June) over New Delhi during March to June 2006. Another study by Satheesh et al. (2006) have examined the impact of dust aerosols on TOA albedo and radiative forcing especially over desert regions (African and Arabian regions) under high surface reflection conditions. They have reported that the TOA albedo becomes less than that of surface albedo over deserts due to absorbing nature of dust aerosols.

Results show that surface level radiative forcing at both the stations is primarily governed by the magnitude of AOD values. However, the TOA forcing is very intricately dependent on several parameters such as AOD, surface albedo, SSA which in turn depends on the real and imaginary components of refractive indices and asymmetry parameter (Satheesh, 2002; Andrews et al., 2006). Satheesh (2002) has done detailed analysis of aerosol forcing by considering different cases of surface albedo and suggested that due to the high 
Table 3. Mean heating rate values $\left(\mathrm{Kday}^{-1}\right)$ at different stations over IGB region during pre-monsoon.

\begin{tabular}{ccc}
\hline \multirow{2}{*}{ Month (2009) } & \multicolumn{2}{c}{ Heating rate $\left(\mathrm{Kday}^{-1}\right)$ at } \\
\cline { 2 - 3 } & Kanpur & Gandhi College \\
\hline April & 0.55 & 0.59 \\
May & 0.55 & 0.45 \\
June & 0.45 & 0.47 \\
\hline
\end{tabular}

surface albedo (e.g. for soil surface), the aerosols forcing at the TOA will change its sign from negative to positive. Furthermore, Satheesh et al. (2002) have shown that if the INDOEX model was used over land (having higher surface reflectance), TOA forcing becomes positive from negative over ocean, which results in increased atmospheric forcing by $\sim 7 \mathrm{~W} \mathrm{~m}^{-2}$. In the present study, however, surface albedo values at Kanpur was found to be relatively lower as compared to that at Gandhi College and vice-versa was found with SSA at both the stations, which decides the magnitude and sign of aerosol forcing at the TOA.

The uncertainty in the radiative forcing calculation in the present case may arise from the difference in the used tropical model atmospheric condition and the real atmosphere, deviations in the surface albedo values, uncertainty in the aerosol parameters retrieved from sun/sky radiometer. The overall uncertainty in the estimated radiative forcing due to deviations in simulation is found in the range about $10-15 \%$. Recently, Dey and Tripathi (2008) have also reported various sources of uncertainties in estimating the aerosol direct radiative forcing during clear- and cloudy-sky conditions over Kanpur in the IGB region. They have estimated the total uncertainty of $\sim 15 \%$ in the estimations of clear-sky aerosol direct radiative forcing, and suggested that the uncertainty may be reduced with an increased number of in-situ measurements of various aerosol parameters at better temporal and spatial resolutions.

\subsection{Atmospheric heating rate due to aerosol}

An important aspect is the aerosol generated atmospheric heating, which can be estimated by following Liou (2002) as

$$
\frac{\partial T}{\partial t}=\frac{g}{C_{p}} \frac{\Delta F}{\Delta P}
$$

where $\partial T / \partial t$ is the heating rate $\left(\mathrm{Kday}^{-1}\right), g$ is the acceleration due to gravity, $C_{p}$ is the specific heat capacity of air at constant pressure, $\Delta F$ is the resultant atmospheric forcing and $\Delta P$ is the atmospheric pressure difference between top and bottom boundary of each layer.

Table 3 shows monthly mean heating rates as 0.55 and $0.59 \mathrm{~K} \mathrm{day}^{-1}$ during April, 0.55 and $0.45 \mathrm{Kday}^{-1}$ during
May and 0.45 and $0.47 \mathrm{Kday}^{-1}$ during June at Kanpur and Gandhi College, respectively. The present result of net atmospheric absorption is comparable with the INDOEX results, where the atmospheric heating rate was estimated to be about $0.5 \mathrm{~K} \mathrm{day}^{-1}$ (Satheesh et al., 2002). However, Dey and Tripathi (2008) have reported the annual mean clear-sky atmospheric heating rate of about $0.84 \mathrm{~K} \mathrm{day}^{-1}$ over Kanpur. The high surface cooling due to negative forcing at the surface and strong heating due to positive aerosol forcing in the atmosphere at both the stations during pre-monsoon indicates their association with various aerosol properties including size and chemical composition of aerosols, which raises several climatic issues. The observed atmospheric heating rate implies that the excess energy in the region is trapped in the atmosphere during dry season, which can have significant impact on regional climate and monsoon circulation systems (Ramanathan et al., 2007; Pilewskie, 2007). Anomalous atmospheric heating due to absorbing aerosols over northern India during pre-monsoon season has been reported by Lau et al. (2006), which was interpreted as increased dust loading coupled with black carbon emissions from the local sources in northern India during pre-monsoon may lead to an advancement of the rainy period and subsequently, can impact for the intensification of the Indian summer monsoon (Gautam et al., 2009a).

\section{Conclusions}

Simultaneous measurements of aerosol optical properties carried out by AERONET at Kanpur and Gandhi College- a typical representative stations of central and eastern IGB region, during April-June 2009 have been used to investigate pre-monsoon aerosol characteristics in terms of their implications to climatic impact. Results also indicate a significant spatial difference in aerosol characteristics between central and eastern IGB region which lead to a considerable asymmetry in aerosol radiative forcing between the regions. The salient results of the present study are given here under:

1. A gradual increase in AOD at each station and relatively large positive gradient in Angstrom exponent as compare to AOD from Kanpur to Gandhi College suggests an increased aerosol loading having markable difference in aerodynamic size range of volume of aerosols from coarse- to fine-mode. Results may be caused due to diverse geographical position of both the stations having diverse meteorological conditions and emission sources.

2. Large SSA $(>0.85)$ was observed at both the stations, which was found to be relatively lower at Gandhi College (0.89) as compared to Kanpur (0.92) and suggested relative dominance of absorbing aerosols at Gandhi College than at Kanpur. 
3. The magnitude of AAE shows an enhancement over the AAE value of 1.0 at both the stations, which was more prominent at Kanpur as compare to Gandhi College. A negative gradient in the magnitude of AAE from Kanpur to Gandhi College suggests that the atmospheric absorption over the central IGB (Kanpur) region could mainly be due to dominance of coarse-mode dust particles and over the eastern IGB (Gandhi College) region, it could be due to dominance of fine-particle pollution.

4. Large TOA and surface forcing was observed at both the stations which were found to be relatively larger at Gandhi College as compare to Kanpur. The resultant atmospheric forcing exerts significant heating to the atmosphere at both the stations ranging from 0.45 to $0.55 \mathrm{~K} \mathrm{day}^{-1}$ at Kanpur and from 0.45 to $0.59 \mathrm{~K} \mathrm{day}^{-1}$ at Gandhi College. Results are largely associated with measured aerosol parameters, which are mainly influenced by the synoptic condition, emission sources and geography of the locations.

The present study reveals that, during pre-monsoon, there are different aerosol characteristics at central and eastern IGB region, which show significant gradients in magnitude of most of the aerosol characteristics over central to eastern sectors of the IGB. Such gradient can be due to the gradual changes in weather parameters and/or emission sources during subsequent months of the pre-monsoon season. Such gradient is, ultimately, found to impact the Earth-atmosphere system by negative radiative forcing, thus causing cooling, at the surface, and positive aerosol forcing, thus causing heating in the atmosphere for the study period. Such gradient in heating rate raises several climatic issues, and is needed to be answered on the basis of longer period investigations at several stations to improve the scientific understanding of the regional climate in inter-annual as well as intra-seasonal scale.

\section{Supplementary material related to this article is available online at: http://www.ann-geophys.net/29/789/2011/ angeo-29-789-2011-supplement.pdf.}

Acknowledgements. Authors are thankful to the AERONET group of NASA, USA for sun/sky radiometers data (http://aeronet.gsfc. nasa.gov/) and NOAA-ARL for the HYSPLIT air mass backtrajectories. We are thankful to A. K. Mishra from FSU, USA for providing the synoptic meteorological plots. Thanks are also due to B. N. Goswami, Director, IITM, Pune for his encouragements and infrastructure supports. Author MKS is thankful to ISRO-ARFI and author SNT is thankful to DST, ICRP, ISRO-GBP and NASA Postdoctoral Program for funding support. Authors are grateful to the two anonymous reviewers for their constructive comments and suggestions, which helped to improve the scientific content of the manuscript.

Topical Editor P. M. Ruti thanks two anonymous referees for their help in evaluating this paper.

\section{References}

Andrews, E., Sheridan, P. J., Fiebig, M., McComiskey, A., Ogren, J. A., Arnott, P., Covert, D., Elleman, R., Gasparini, R., Collins, D., Jonsson, H., Schmid, B., and Wang, J.: Comparison of methods for deriving aerosol asymmetry parameter, J. Geophys. Res., 111, D05S04, doi:10.1029/2004JD005734, 2006.

Ångström, A.: The parameters of atmospheric turbidity, Tellus, 16, 64-75, 1964.

Badarinath, K. V. S., Kharol, S. K., and Sharma, A. R.: Long-range transport of aerosols from agriculture crop residue burning in Indo-Gangetic Plains-A study using LIDAR, ground measurements and satellite data, J. Atmos. Solar-Terr. Phys., 71, 112120, 2009.

Bergstrom, R. W., Pilewskie, P., Russell, P. B., Redemann, J., Bond, T. C., Quinn, P. K., and Sierau, B.: Spectral absorption properties of atmospheric aerosols, Atmos. Chem. Phys., 7, 5937-5943, doi:10.5194/acp-7-5937-2007, 2007.

Collaud Coen, M., Weingartner, E., Schaub, D., Hueglin, C., Corrigan, C., Henning, S., Schwikowski, M., and Baltensperger, U.: Saharan dust events at the Jungfraujoch: detection by wavelength dependence of the single scattering albedo and first climatology analysis, Atmos. Chem. Phys., 4, 2465-2480, doi:10.5194/acp4-2465-2004, 2004.

D’Almeida, G. A., Koepke, P., and Shettle, E. P.: Atmospheric Aerosols: Global Climatology and Radiative Characteristics, A. Deepak, Hampton, Va, 1991.

Dey, S. and Di Girolamo, L.: A climatology of aerosol optical and microphysical properties over the Indian subcontinent from 9 years (2000-2008) of Multiangle Imaging Spectroradiometer (MISR) data, J. Geophys. Res., 115, D15204, doi:10.1029/2009JD013395, 2010.

Dey, S. and Tripathi, S. N.: Aerosol direct radiative effects over Kanpur in the Indo-Gangetic basin, northern India: Long-term (2001-2005) observations and implications to regional climate, J. Geophys. Res., 113, D04212, doi:10.1029/2007JD009029, 2008.

Dey, S., Tripathi, S. N., Singh, R. P., and Holben, B. N.: Influence of dust storms on the aerosol optical properties over the Indo-Gangetic basin, J. Geophys. Res., 109, D20211, doi:10.1029/2004JD004924, 2004.

Dey, S., Tripathi, S. N., and Mishra, S. K.: Probable mixing state of aerosols in the Indo-Gangetic Basin, northern India, Geophys. Res. Lett., 35, L03808, doi:10.1029/2007GL032622, 2008.

Di Girolamo, L., Bond, T. C., Bramer, D., Diner, D. J., Fettinger, F., Kahn, R. A., Martonchik, J. V., Ramana, M. V., Ramanathan, V., and Rasch, P. J.: Analysis of Multi-angle Imaging SpectroRadiometer (MISR) aerosol optical depths over greater India during winter 2001-2004, Geophys. Res. Lett., 31, L23115, doi:10.1029/2004GL021273, 2004.

Draxler, R. R. and Rolph, G. D.: HYSPLIT (Hybrid Single-Particle Lagrangian Integrated Trajectory) model, NOAA Air Resources Laboratory, Silver Spring, MD, 2003.

Dubovik, O., Smirnov, A., Holben, B. N., King, M. D., Kaufman, Y. J., Eck, T. F., and Slutsker, I.: Accuracy assessments of aerosol optical properties retrieved from Aerosol Robotic Network (AERONET) Sun and sky radiance measurements, J. Geophys. Res., 105, 9791-9806, 2000.

Eck, T. F., Holben, B. N., Dubovik, O., Smirnov, A., Goloub, P., Chen, H. B., Chatenet, B., Gomes, L., Zhang, X.-Y., Tsay, S.-C., 
Ji, Q., Giles, D., and Slutsker, I.: Column aerosol optical properties at AERONET sites in central eastern Asia and aerosol transport to the tropical mid-Pacific, J. Geophys. Res., 110, D06202, doi:10.1029/2004JD005274, 2005.

Eck, T. F., Holben, B. N., Sinyuk, A., Pinker, R. T., Goloub, P., Chen, H., Chatenet, B., Li, Z., Singh, R. P., Tripathi, S. N., Reid, J. S., Giles, D. M., Dubovik, O., O.Neill, N. T., Smirnov, A., Wang, P., and Xia, X.: Climatological aspects of the optical properties of fine/coarse mode aerosol mixtures, J. Geophys. Res., 115, D19205, doi:10.1029/2010JD014002, 2010.

Ganguly, D., Ginoux, P., Ramaswamy, V., Dubovik, O., Welton, J., Reid, A. E., and Holben, B. N.: Inferring the composition and concentration of aerosols by combining AERONET and MPLNET data: Comparison with other measurements and utilization to evaluate GCM output, J. Geophys. Res., 114, D16203, doi:10.1029/2009JD011895, 2009.

Gautam, R., Hsu, N. C., Lau, K.-M., and Kafatos, M.: Aerosol and rainfall variability over the Indian monsoon region: distributions, trends and coupling, Ann. Geophys., 27, 3691-3703, doi:10.5194/angeo-27-3691-2009, 2009a.

Gautam, R., Liu, Z., Singh, R. P., and Hsu, N. C.: Two contrasting dust-dominant periods over India observed from MODIS and CALIPSO data, Geophys. Res. Lett., 36, L06813, doi:10.1029/2008GL036967, 2009b.

Guttikunda, S. K., Carmichael, G. R., Calori, G., Eck, C., and Woo, J. H.: The contribution of mega cities to regional sulfur pollution in Asia, Atmos. Environ., 37(1), 11-22, 2003.

Habib, G., Venkataraman, C., Chiapello, I., Ramachandran, S., Boucher, O., and Reddy, M. S.: Seasonal and inter-annual variability in absorbing aerosols over India derived TOMS: Relationship to regional meteorology and emissions, Atmos. Environ., 40, 1909-1921, 2006.

Holben, B. N., Eck, T. F., Slutsker, I., Tanre, D., Buis, J. P., Setzer, A., Vermote, E., Reagan, J. A., Kaufman, Y. J., Nakajima, T., Lavenu, F., Jankowiak, I., and Smirnov, A.: AERONET - A federated instrument network and data archive for aerosol characterization, Remote Sens. Environ., 66, 1-16, 1998.

Holben, B. N., Tanr, D., Smirnov, A., Eck, T. F., Slutsker, I., Abuhassan, N., Newcomb, W. W., Schafer, J. S., Chatenet, B., Lavenu, F., Kaufman, Y. J., Vande Castle, J., Setzer, A., Markham, B., Clark, D., Frouin, R., Halthore, R., Karneli, A., O’Neill, N. T., Pietras, C., Pinker, R. T., Voss, K., and Zibordi, G.: An emerging ground-based aerosol climatology: Aerosol optical depth from AERONET, J. Geophys. Res., 106, 1206712098, 2001.

Hoppel, W. A., Fitzgerald, J. W., and Larson, R. E.: Aerosol size distributions in air masses advecting off the east coast of the United States, J. Geophys. Res., 90, 2365-2379, 1985.

Intergovernmental Panel on Climate Change (IPCC): Climate change 2007: The physical science basis: Contribution of Working Group I to the Fourth Assessment Report of the Intergovernmental Panel on Climate Change, Chapter 2, 129 pp., 2007.

Jethva, H., Satheesh, S. K., and Srinivasan, J.: Seasonal variability of aerosols over the Indo-Gangetic basin, J. Geophys. Res., 110, D21204, doi:10.1029/2005JD005938, 2005.

Lau, K.-M., Kim, M. K., and Kim, K. M.: Asian summer monsoon anomalies induced by aerosol direct forcing: The role of the Tibetan Plateau, Clim. Dynam., 26(7-8), 855-864, doi:10.1007/s00382-006-0114-z, 2006.
Lemaître, C., Flamant, C., Cuesta, J., Raut, J.-C., Chazette, P., Formenti, P., and Pelon, J.: Radiative heating rates profiles associated with a springtime case of Bodélé and Sudan dust transport over West Africa, Atmos. Chem. Phys., 10, 8131-8150, doi:10.5194/acp-10-8131-2010, 2010.

Li, Z., Xia, X., Cribb, M., Mi, W., Holben, B. N., Wang, P., Chen, H., Tsay, S.-C., Eck, T. F., Zhao, F., Dutton, E. G., and Dickerson, R. E.: Aerosol optical properties and their radiative effects in northern China, J. Geophys. Res., 112, D22S01, doi:10.1029/2006JD007382, 2007.

Liou, K. N.: An Introduction to Atmospheric Radiation, Elsevier, New York, 583 pp., 2002.

Massie, S. T., Torres, O., and Smith, S. J.: Total Ozone Mapping Spectrometer (TOMS) observations of increases in Asian aerosol in winter from 1979 to 2000, J. Geophys. Res., 109, D18211, doi:10.1029/2004JD004620, 2004.

Middleton, N. J.: A geography of dust storms in south west Asia, Int. J. Climatol., 6, 183-196, doi:10.1002/joc.3370060207, 1986.

Mishra, S. K., Dey, S., and Tripathi, S. N.: Implications of particle composition and shape to dust radiative effect: A case study from the Great Indian Desert, Geophys. Res. Lett., 35, L23814, doi:10.1029/2008GL036058, 2008.

Monkkonen, P., Uma, R., Srinivasan, D., Koponen, I. K., Lehtinen, K. E. J., Hameri, K., Suresh, R., Sharma, V. P., and Kulmala, M.: Relationship and variations of aerosol number and $\mathrm{PM}_{10}$ mass concentrations in a highly polluted urban environment-New Delhi, India, Atmos. Environ., 38, 425-433, 2004.

Moorthy, K. K., Saha, A., Prasad, B. S. N., Niranjan, K., Jhurry, D., and Pillai, P. S.: Aerosol optical depths over peninsular India and adjoining oceans during the INDOEX campaigns: Spatial, temporal, and spectral characteristics, J. Geophys. Res., 106(D22), 28539-28554, 2001.

Pandithurai, G., Dipu, S., Dani, K. K., Tiwari, S., Bisht, D. S., Devara, P. C. S., and Pinker, R. T.: Aerosol radiative forcing during dust events over New Delhi, India, J. Geophys. Res., 113, D13209, doi:10.1029/2008JD009804, 2008.

Pilewskie, P.: Climate change: Aerosols heat up, Nature, 448, 541542, doi:10.1038/448541a, 2007.

Prasad, A. K. and Singh, R. P.: Changes in aerosol parameters during major dust storm events (2001-2005) over the Indo-Gangetic Plains using AERONET and MODIS data, J. Geophys. Res., 112, D09208, doi:10.1029/2006JD007778, 2007.

Prasad, A. K., Singh, S., Chauhan, S. S., Srivastava, M. K., Singh, R. P., and Singh, R.: Aerosol radiative forcing over the IndoGangatic plains during major dust storms, Atmos. Environ., 41, 6289-6301, 2007.

Ram, K. and Sarin, M. M.: Spatio-temporal variability in atmospheric abundances of EC, OC and WSOC over Northern India, J. Aerosol Sci., 41, 88-98, 2010.

Ramachandran, S. and Cherian, R.: Regional and seasonal variations in aerosol optical characteristics and their frequency distributions over India during 2001-2005, J. Geophys. Res., 113, D08207, doi:10.1029/2007JD008560, 2008.

Ramachandran, S. and Rajesh, T. A.: Asymmetry parameters in the lower troposphere derived from aircraft measurements of aerosol scattering coefficients over tropical India, J. Geophys. Res., 113, D16212, doi:10.1029/2008JD009795, 2008.

Ramanathan, V. and Ramana, M. V.: Persistent, widespread, and strongly absorbing haze over the Himalayan foothills and the 
Indo-Ganges plains, Pure Appl. Geophys., 162, 1609-1626, 2005.

Ramanathan, V., Crutzen, P. J., Lelieveld, J., Mitra, A. P., Althausen, D., Andersons, J., Andreae, M. O., Cantrell, W., Cass, G. R., Chung, C. E., Clarke, A. D., Coakley, J. A., Collins, W. D., Conant, W. C., Dulac, F., Heintzenberg, J., Heymsfield, A. J., Holben, B. N., Howell, S., Hudson, J., Jayaraman, A., Kiehl, J. T., Krishnamurti, T. N., Lubin, D., McFarquhar, G., Novakov, T., Ogren, J. A., Podgorny, I. A., Prather, K., Priestley, K., Prospero, J. M., Quinn, P. K., Rajeev, K., Rasch, P., Rupert, S., Sadourny, R., Satheesh, S. K., Shaw, G. E., Sheridan, P., and Valero, F. P. J.: Indian Ocean Experiment: An integrated analysis of the climate forcing and effects of the great Indo-Asian haze, J. Geophys. Res., 106, 28371-28398, 2001.

Ramanathan, V., Ramana, M. V., Roberts, G., Kim, D., Corrigan, C., Chung, C., and Winker, D.: Warming trends in Asia amplified by brown cloud solar absorption, Nature, 448, 575-578, 2007.

Raut, J.-C. and Chazette, P.: Radiative budget in the presence of multi-layered aerosol structures in the framework of AMMA SOP-0, Atmos. Chem. Phys., 8, 6839-6864, doi:10.5194/acp-86839-2008, 2008.

Reddy, M. S. and Venketaraman, C.: Inventories of aerosols and sulphur dioxide emissions from India: I. Fossil fuel combustion, Atmos. Environ., 36, 677-697, 2002a.

Reddy, M. S. and Venketaraman, C.: Inventories of aerosols and sulphur dioxide emissions from India: II. Biomass combustion, Atmos. Environ., 36, 699-712, 2002b.

Rengarajan, R., Sarin, M. M., and Sudheer, A. K.: Carbonaceous and inorganic species in atmospheric aerosols during wintertime over urban and high-altitude sites in North India, J. Geophys. Res., 112, D21307, doi:10.1029/2006JD008150, 2007.

Ricchiazzi, P., Yang, S., Gautier, C., and Sowle, D.: SBDART: A research and teaching tool for plane-parallel radiative transfer in the Earth's atmosphere, B. Am. Meteorol. Soc., 79, 2101-2114, 1998.

Russell, P. B., Bergstrom, R. W., Shinozuka, Y., Clarke, A. D., DeCarlo, P. F., Jimenez, J. L., Livingston, J. M., Redemann, J., Dubovik, O., and Strawa, A.: Absorption Angstrom Exponent in AERONET and related data as an indicator of aerosol composition, Atmos. Chem. Phys., 10, 1155-1169, doi:10.5194/acp10-1155-2010, 2010.

Satheesh, S. K.: Letter to the Editor: Aerosol radiative forcing over land: effect of surface and cloud reflection, Ann. Geophys., 20, 2105-2109, doi:10.5194/angeo-20-2105-2002, 2002.

Satheesh, S. K., Ramanathan, V., Holben, B. N., Moorthy, K. K., Loeb, N. G., Maring, H., Prospero, J. M., and Savoie, D.: Chemical, microphysical, and radiative effects of Indian Ocean aerosols, J. Geophys. Res., 107(D23), 4725, doi:10.1029/2002JD002463, 2002.

Satheesh, S. K., Deepshikha, S., and Srinivasan, J.: Impact of dust aerosols on Earth-atmosphere clear-sky albedo and its short wave radiative forcing over African and Arabian regions, Int. J. Remote Sens., 27(8), 1691-1706, 2006.

Schwartz, S. E., Arnold, F., Blanchet, J.-P., Durkee, P.A., Hofmann, D. J., Hoppel, W. A., King, M. D., Laos, A. A., Nakajima, T., Ogren, J. A., Toon, O. B., and Wendisch, M.: Group Report: Connections between aerosol properties and forcing of climate, John Wiley, Hoboken, N. J., pp. 251-280, 1995.

Sharma, Anu Rani, Shailesh Kumar Kharol, Badarinath, K. V. S., and Darshan Singh: Impact of agriculture crop residue burning on atmospheric aerosol loading - a study over Punjab State, India, Ann. Geophys., 28, 367-379, doi:10.5194/angeo-28-3672010, 2010.

Singh, R. P., Dey, S., Tripathi, S. N., Tare, V., and Holben, B.: Variability of aerosol parameters over Kanpur, northern India, J. Geophys. Res., 109, D23206, doi:10.1029/2004JD004966, 2004.

Singh, S., Nath, S., Kohli, R., and Singh, R.: Aerosols over Delhi during pre-monsoon months: Characteristics and effects on surface radiation forcing, Geophys. Res. Lett., 32, L13808, doi:10.1029/2005GL023062, 2005.

Singh, S., Soni, K., Bano, T., Tanwar, R. S., Nath, S., and Arya, B. C.: Clear-sky direct aerosol radiative forcing variations over mega-city Delhi, Ann. Geophys., 28, 1157-1166, doi:10.5194/angeo-28-1157-2010, 2010.

Smirnov, A., Holben, B. N., Eck, T. F., Dubovik, O., and Slutsker, I.: Cloud screening and quality control algorithms for the AERONET database, Remote Sens. Environ., 73(3), 337-349, 2000.

Srivastava, A. K., Devara, P. C. S., Rao, Y. J., Bhavanikumar, Y., and Rao, D. N.: Aerosol optical depth, ozone and water vapor measurements over Gadanki, a tropical station in peninsular India, Aerosol Air Qual. Res., 8(4), 459-476, 2008.

Srivastava, A. K., Pant, P., Hegde, P., Singh, S., Dumka, U. C., Naja, M., Singh, N., and Bhavanikumar, Y.: Influence of south Asian dust storm on aerosol radiative forcing at a high-altitude station in central Himalayas, Int. J. Remote Sens., accepted, 2010a.

Srivastava, M. K., Srivastava, S. K., Saha, A., Tiwari, S., Singh, S., Dumka, U. C., Singh, B. P., Singh, N. P.: Aerosol optical properties over Delhi and Manora Peak during a rare dust event in early April 2005, Int. J. Remote Sens., accepted, 2010b.

Srivastava, A. K., Tiwari, S., Bisht, D. S., Devara, P. C. S., Goloub, P., Li, Z., and Srivastava, M. K.: Optical characteristics of aerosols and radiative forcing for the coolest June month over Delhi, India, Int. J. Remote Sens., accepted, 2010c.

Tare, V., Tripathi, S. N., Chinnam, N., Srivastava, A. K., Dey, S., Manar, M., Kanwade, V. P., Agarwal, A., Kishore, S., Lal, R. B., and Sharma, M.: Measurements of atmospheric parameters during Indian Space Research Organization Geosphere Biosphere Program Land Campaign II at a typical location in the Ganga Basin: 2. Chemical properties, J. Geophys. Res., 111, D23210, doi:10.1029/2006JD007279, 2006.

Tiwari, S., Srivastava, A. K., Bisht, D. S., Bano, T., Singh, S., Behura, S., Srivastava Manoj K., Chate D. M., and Padmanabhamurty, B.: Black carbon and chemical characteristics of $\mathrm{PM}_{10}$ and $\mathrm{PM}_{2.5}$ at an urban site of North India, J. Atmos. Chem., 62(3), 193-209, doi:10.1007/s10874-010-9148-z, 2010.

Todd, M. C., Washington, R., Martins, J. V., Dubovik, O., Lizcano, G., M'Bainayel, S., and Engelstaedter, S.: Mineral dust emission from the Bodélé Depression, northern Chad, during BoDEx 2005, J. Geophys. Res., 112, D06207, doi:10.1029/2006JD007170, 2007.

Tripathi, S. N., Dey, Sagnik, Chandel, A., Srivastava, S., Singh, Ramesh P., and Holben, B. N.: Comparison of MODIS and AERONET derived aerosol optical depth over the Ganga Basin, India, Ann. Geophys., 23, 1093-1101, doi:10.5194/angeo-231093-2005, 2005.

Tripathi, S. N., Tare, V., Chinnam, N., Srivastava, A. K., Dey, S., Agarwal, A., Kishore, S., Lal, R. B., Manar, M., Kanawade, V. 
P., Chauhan, S. S. S., Sharma, M., Reddy, R. R., Gopal, K. R., Narasimhulu, K., Reddy, L. S. S., Gupta, S., and Lal, S.: Measurements of atmospheric parameters during Indian Space Research Organization Geosphere Biosphere Programme Land
Campaign II at a typical location in the Ganga Basin: 1. Physical and optical properties, J. Geophys. Res., 111, D23209, doi:10.1029/2006JD007278, 2006. 